\title{
On the Use of Load-Transformation Matrices When Working with Internal Wind Tunnel Balances
}

\author{
Đorđe Vuković \\ Lead Research Enginee \\ Experimental Aerodynamics Department \\ Military Technical Institute Belgrade \\ Dijana Damljanović \\ Lead Research Enginee \\ Experimental Aerodynamics Department \\ Military Technical Institute Belgrade
}

Internal wind tunnel balances are often classified by the design as "force", "moment" or "direct-read" balances. Only the direct-read balances can immediately yield the total loads; with other designs, balance-type-specific transformations of actually measured loads to total loads are necessary. It is shown that a representation of these transformations in matrix form, as a "load transformation matrix", beside being a convenient method to perform the calculations, enables significant generalizations in data processing, practically dispensing with the "type" of a balance. The use of a transformation matrix also facilitates exchanges of balance calibration data or the balances themselves between wind tunnel communities using different axes- and component-sign conventions. It is proposed that, because of the advantages it offers, the load transformation matrix be generally used to describe balance designs and to accompany a balance together with a calibration matrix.

Keywords: wind tunnel balance, transformation matrix.

\section{INTRODUCTION}

Internal wind tunnnel balances, possibly the most important tools of experimental aerodynamics, are multi-component force sensors that are used to measure total aerodynamic loads on wind tunnel test objects and resolve them into principal components of axial force $X$, side force $Y$, normal force $Z$, rolling moment $L$, pitching moment $M$ and yawing moment $N$. Measurement is commonly achieved by acquiring and processing the signals from strain gauge bridges sensing the minute elastic deformations of certain parts of the balance subjected to load. These actually-measured local loads (physical-components loads) may or may not be equivalent to components of total loads, depending on a particular balance design.

Measured component loads are obtained by applying a calibration matrix to the signals from strain gauge bridges on the balance. In the prevailing iterative model [1] of the balance, the relation between the physicalcomponents loads $\{F\}$ and normalized output signals $\{e\}$ from strain gauge bridges is expressed as:

$$
\{e\}=[C 1]\{F\}+[C 2]\left\{F^{*}\right\}
$$

where [C1] and [C2] are the linear and the nonlinear part of a balance calibration matrix $[C]=[C 1 \mid C 2]$ and $\left\{F^{*}\right\}$ is the vector of load products, containing suitable simple (e.g. polynomial) functions of the members of $\{F\}$, and modelling the slightly nonlinear behaviour of the balance. Component loads $\{F\}$ are computed from

Received: February 2014, Accepted: May 2014

Correspondence to: Đorđe Vuković

Military Technical Institute (VTI)

Ratka Resanovića 1, 11030 Beograd, Serbia

E-mail: vdjole@sbb.rs

doi:10.5937/fmet1501021V

(C) Faculty of Mechanical Engineering, Belgrade. All rights reserved
(1) in a number of converging iterations $i$ as:

$$
\{F\}=\lim _{i \rightarrow \infty}\{F\}_{i}=\lim _{i \rightarrow \infty}\left([C 1]^{-1}\{e\}-[C 1]^{-1}[C 2]\left\{F^{*}\right\}_{i-1}\right)
$$

While the mathematical model (1) can be applied to all balance designs, the transformations needed to combine physical-components loads into total loads, are balance-design dependent. This paper presents a logical concept by which that procedure can be generalized, and its dependence on balance design eliminated.

\section{TRANSFORMATIONS FROM COMPONENT LOADS TO TOTAL LOADS}

According to their design, internal wind tunnel balances can be generally classified into several basic types. The well-known reference [1] notes the existence of the "force", "moment" and "direct-read", balances, depending on whether the strain gauges on a balance are positioned and wired so that the majority of the "physical" (i.e. actually measured) load components are forces, moments, or a particular combination of the two.

Of the main three types of internal wind tunnel balances, only the direct-read six-component balance, measuring three components of force and three components of moments, can immediately yield the total loads ( $X, Y, Z, L, M, N$ ), reduced to the balance moment reduction centre (BMC), from loads $\{F\}=\left\{F_{X}, F_{Y}, F_{Z}, M_{X}, M_{Y}, M_{Z}\right\}^{T}$ on physical balance components:

$$
\begin{aligned}
& X=F_{X} \\
& Y=F_{Y} \\
& Z=F_{Z} \\
& L=M_{X} \\
& M=M_{Y} \\
& N=M_{Z}
\end{aligned}
$$


With all other balance types, a transformation of physical-components loads to total loads is necessary. This transformation is dependent on the design of a balance, but also on the conventions regarding the orientations of axes systems and positive directions of load components.

Unfortunately, neither the orientations of the axes systems, nor the conventions for positive directions of the forces and moments acting on a wind tunnel balance nor the order (sequence) of load components are universal. While weight and trust are positive in most of West-European wind tunnel practice (Fig. 1), lift (or normal force) and drag (or axial force) are defined as positive in the North-American practice (Fig. 2), and, contrary to European practice, they are not all positive in the same directions as the axes. The European system is mathematically consistent (right-handed), while the American one is not [2][3][4].

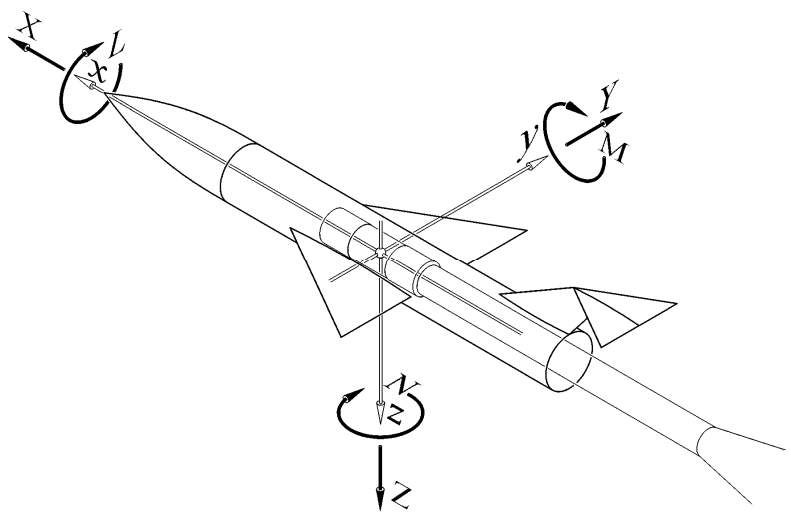

Figure 1. Positive directions of axes and load components in West-European wind tunnel practice

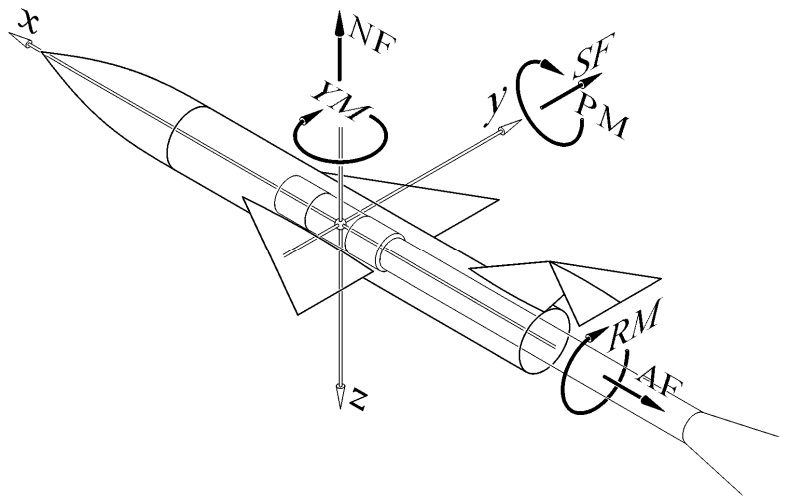

Figure 2. Positive directions of axes and load components in North-American wind tunnel practice

There are other conventions as well: e.g. in Russian wind tunnel practice [5][6], a right-handed system is used, with the $y$-axis being in the direction of lift, not parallel to the side force (Fig. 3). Also, at some wind tunnel sites, e.g. [7][8], positive directions of forces and moments are in accordance with a mathematically consistent left-handed system, having lift and drag as positive, with positive side force being in the direction opposite to that in the prevailing West-European and North-American practice.

It can be noticed from Fig. 1 to Fig. 3 that the nomenclatures for components of aerodynamic loads are different in different communities. Besides, the order (sequence) of components of total loads in European practice follows the $x, y, z, \ldots$ sequence of axes for the axial-, side- and normal force components followed by the three moments components around the these axes (i.e. $X, Y, Z, L, M, N)$, while e.g. the sequence and names of components in recommended North-American practice [1] are $N F, P M, S F, Y M, R M, A F$ (normal force, pitching moment, side force ...etc.).

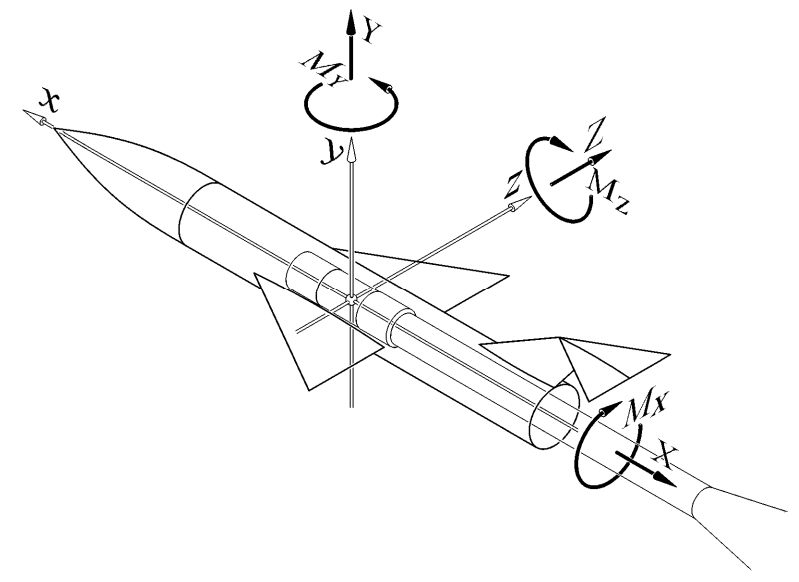

Figure 3. Positive directions of axes and load components in Russian wind tunnel practice

In contrast to the identity transformations (3) for the direct-read balances, load transformations for the main "moment" and "force" balance types are given below, in accordance with the West-European conventions and with some comparisons to the North-American ones.

A typical six-component "moment balance" (Fig. 4) is most often a mono-bloc cantilevered-beam design that has five physical components measuring moments and one physical component measuring axial force. Instrumented sections sensing bending and torsional moments of the balance-beam are usually symmetrically arranged around the BMC.

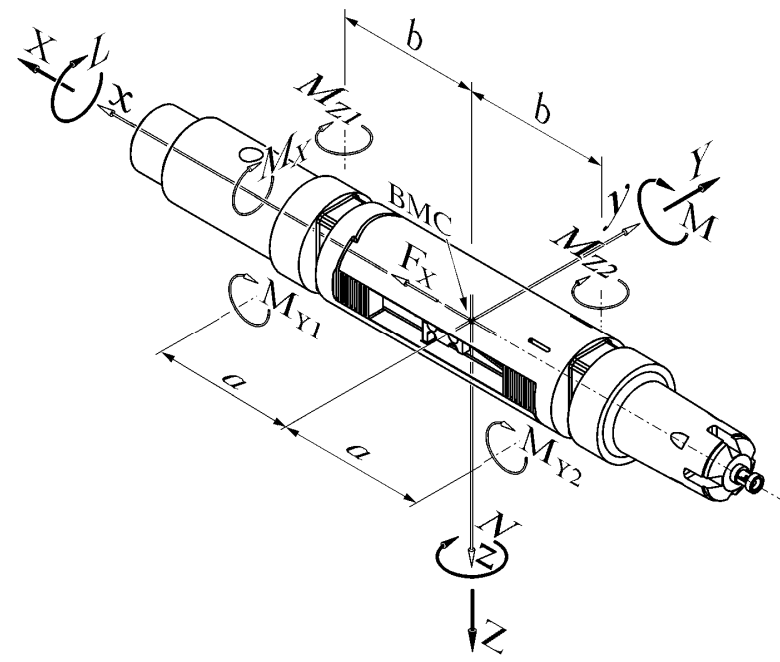

Figure 4. Physical and total-load components of a typical moment balance

Assuming a mathematically consistent right-handed axes system and the European convention for positive directions of total loads, the equations for load transformation from physical-components loads to total loads have the well-known form, e.g. adapted from [1] [9]: 


$$
\begin{aligned}
& X=F_{X} \\
& Y=-0.5 / b \cdot M_{Z 1}+0.5 / b \cdot M_{Z 2} \\
& Z=0.5 / a \cdot M_{Y 1}-0.5 / a \cdot M_{Y 2} \\
& L=M_{X} \\
& M=0.5 \cdot M_{Y 1}+0.5 \cdot M_{Y 2} \\
& N=0.5 \cdot M_{Z 1}+0.5 \cdot M_{Z 2}
\end{aligned}
$$

A typical six-component "force balance" is similar to the six-component balances that were produced by the Able (formerly Task) Corporation and is often referred to as an "Able/Task balance". A force balance of this type has five physical components measuring forces and one component measuring rolling moment. Force-sensing elements are symmetrically arranged about the BMC. The positive directions of physicalcomponents loads on an Able/Task balance are in accordance with the North-American practice. The names and sequence of physical components are declared by the manufacturer in accordance with NorthAmerican practice, i.e. $N F 1, N F 2, S F 1, S F 2, R M, A F$. In European notation and axis conventions (Fig. 5), these would be $F_{Z 1}, F_{Z 2}, F_{Y 1}, F_{Y 2}, M_{X}, F_{X}$, respectively.

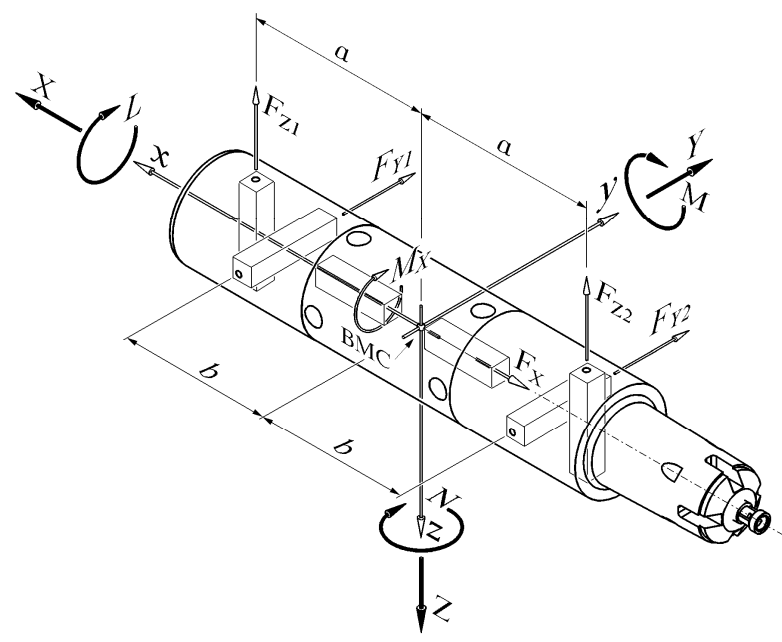

Figure 5. Physical and total-load components of a typical Able/Task-type force balance

The equations for transformations from component loads to total loads are:

$$
\begin{aligned}
& X=-F_{X} \\
& Y=F_{Y 1}+F_{Y 2} \\
& Z=-F_{Z 1}-F_{Z 2} \\
& L=M_{X} \\
& M=a \cdot F_{Z 1}-a \cdot F_{Z 2} \\
& N=b \cdot F_{Y 1}-b \cdot F_{Y 2}
\end{aligned}
$$

Beside the Able/Task balance design which is a multi-piece, assembled device, other design solutions of force balances exist as well, including mono-bloc ones. Some of the numerous designs, e.g. [10][11], do not readily fit into definitions [1] of standard balance types.

In (3) to (5) it was implicitly assumed that the physical components of a balance are defined in accordance with actual design of the sensing elements, bit it need not be so. A wind tunnel balance of any design can be calibrated as a direct-read one, logically assigning each of the measuring bridges to one of the components of total loads, so as to immediately yield the total loads and, therefore, dispense with the above transformations (4)(5) at the price of large off-diagonal elements in the calibration matrix, and this is, indeed, the practice in some wind tunnel facilities. Among the main reasons for calibrating and using all balances as the direct-read ones can be that the data-reduction software or balance calibration software or hardware at the user's site does not support a balance of a particular design.

There are, however, several very good arguments against such practice, and it has been rightfully recommended [1][12] that all balances be calibrated in the load format according to their design type. Among the arguments against calibrating a balance in a load format other than its "design" or "native" format are:

- The bi-directionality, often present in multi-piece assembled balances, is hard or impossible to properly account for [1][12];

- The iterative computation of loads from component signals may not converge [13];

- Actual stresses in the sensing elements may not be obvious from computed component loads, so that monitoring of overloads becomes complicated.

The preferred practice would be, therefore, to have the calibration matrix of a wind tunnel balance in its "native" or "design" format, so that the "mathematical" components correspond to the physical measuring components of the balance. After computing physicalcomponents loads from component signals and the calibration matrix using (1) and (2), the proper transformations, specific for a particular balance design and size, should be applied to obtain total loads.

The existing multitude of balance designs, as well as the variations in the conventions regarding the orientation and signs of the axes systems and balance components, can present an inconvenience (to say the least) to an experimenter- a wind tunnel test engineer or a balance calibrating engineer, and also to a programmer coding wind tunnel software. This can happen especially when they face the situations where a new balance type is to be applied that is not supported by the software code at the site, or some balance calibration data has to be imported that originated from another facility that uses different conventions.

There exists, however, an elegant technique that can greatly reduce these inconveniences. It is the treatment of the transformations of physical-components loads to total loads in a matrix form, as a "component load transformation matrix".

\section{LOAD TRANSFORMATIONS IN MATRIX FORM}

The equations (3) to (5), being linear transformations, lend themselves well to matrix representations, but care must be taken about the correct ordering of both the physical components and the components of total loads. In this regard, the best practice might be to adhere to local conventions for the ordering of the components of total loads (because that would normally be the order expected by the wind tunnel data-reduction software at 
the site) but to keep the names, ordering and positive directions of physical components in accordance with the balance manufacturer's documentation, as will be shown in the following examples.

For a direct-read six-component wind tunnel balance, and assuming the West-European conventions, the transformation (3) from physical-components loads to total loads can be represented by an identity matrix:

$$
\left\{\begin{array}{c}
X \\
Y \\
Z \\
L \\
M \\
N
\end{array}\right\}=\left[\begin{array}{llllll}
1 & 0 & 0 & 0 & 0 & 0 \\
0 & 1 & 0 & 0 & 0 & 0 \\
0 & 0 & 1 & 0 & 0 & 0 \\
0 & 0 & 0 & 1 & 0 & 0 \\
0 & 0 & 0 & 0 & 1 & 0 \\
0 & 0 & 0 & 0 & 0 & 1
\end{array}\right] \cdot\left\{\begin{array}{c}
F_{X} \\
F_{Y} \\
F_{Z} \\
M_{X} \\
M_{Y} \\
M_{Z}
\end{array}\right\}
$$

For a typical six-component moment balance, adopting the $F_{X}, M_{X}, M_{Y 1}, M_{Y 2}, M_{Z 1}, M_{Z 2}$ sequence of physical components (as used at the authors' wind tunnel site) and the European conventions for the positive directions of total loads, the transformations (4) can be written in matrix notation as:

$$
\left\{\begin{array}{c}
X \\
Y \\
Z \\
L \\
M \\
N
\end{array}\right\}=\left[\begin{array}{cccccc}
1 & 0 & 0 & 0 & 0 & 0 \\
0 & 0 & 0 & 0 & -0.5 / b & 0.5 / b \\
0 & 0 & 0.5 / a & -0.5 / a & 0 & 0 \\
0 & 1 & 0 & 0 & 0 & 0 \\
0 & 0 & 0.5 & 0.5 & 0 & 0 \\
0 & 0 & 0 & 0 & 0.5 & 0.5
\end{array}\right] \cdot\left\{\begin{array}{c}
F_{X} \\
M_{X} \\
M_{Y 1} \\
M_{Y 2} \\
M_{Z 1} \\
M_{Z 2}
\end{array}\right\}(7)
$$

Again assuming the European conventions for total loads but keeping the manufacturer's conventions for the order and signs of physical-components loads, the transformations (5) for a typical Able/Task-type sixcomponent force balance can be written as:

$$
\left\{\begin{array}{c}
X \\
Y \\
Z \\
L \\
M \\
N
\end{array}\right\}=\left[\begin{array}{cccccc}
0 & 0 & 0 & 0 & 0 & -1 \\
0 & 0 & 1 & 1 & 0 & 0 \\
-1 & -1 & 0 & 0 & 0 & 0 \\
0 & 0 & 0 & 0 & 1 & 0 \\
a & -a & 0 & 0 & 0 & 0 \\
0 & 0 & b & -b & 0 & 0
\end{array}\right] \cdot\left\{\begin{array}{l}
F_{Z 1} \\
F_{Z 2} \\
F_{Y 1} \\
F_{Y 1} \\
M_{X} \\
F_{X}
\end{array}\right\}
$$

In the above examples, the transformations were represented by $6 \times 6$ matrices, but this is not a general case: the number of columns in a transformation matrix should correspond to the number of physical load components. For example, if a three-component directread balance is used, with physical components measuring axial force, normal force and pitching moment, the transformations equivalent to (6) would be:

$$
\left\{\begin{array}{c}
X \\
Y \\
Z \\
L \\
M \\
N
\end{array}\right\}=\left[\begin{array}{lll}
1 & 0 & 0 \\
0 & 0 & 0 \\
0 & 1 & 0 \\
0 & 0 & 0 \\
0 & 0 & 1 \\
0 & 0 & 0
\end{array}\right] \cdot\left\{\begin{array}{l}
F_{X} \\
F_{Z} \\
M_{Y}
\end{array}\right\}
$$

\section{GENERALIZATION OF THE LOAD TRANSFORMATION MATRIX CONCEPT}

The concept of using a load transformation matrix to compute total loads on a wind tunnel balance from physical-components loads is not new but seems to have remained obscure. Although most computations related to multi-component wind tunnel balances are universally performed and discussed using matrix notation and operations, the rather obvious treatment of component-loads transformations in matrix form is, to authors' knowledge, not used anywhere (apart from the authors' wind tunnel site [8][14][15]) explicitly in the published work, and the widely-used references like [1][2][12] etc. make no mention of it.

A rudimentary load transformation-matrix concept was implemented a number of years ago in the wind tunnel software at the Aeronautical institute Žarkovo (VTI), then in Yugoslavia, now a part of the Military Technical Institute in Beograd, Serbia. The actual origin of the basic idea is unclear and the authors lay no claims to its invention by VTI, although no references to its prior uses elsewhere could be found. Transformation matrices were first used just as a convenient way to perform the calculations using library subroutines, the matrix elements and most computations at that time still being hard-coded as particular cases in separate code branches for the few specific balance types then in use at the site. As new balance designs were introduced, a need appeared to unify the data-reduction software for diverse balance types and different model support mechanisms in all wind tunnels of VTI. To this end, one of the authors of this paper has upgraded [8] the wind tunnel data-reduction software in VTI and developed a general-purpose global-regression balance-calibration software tool [16]. Balance component load transformation matrices were systematically applied in these two software products in a much-generalized manner. The author has developed the concept of a generic wind tunnel balance, asserting that all designs of internal wind tunnel balances are, in principle, equal, should be defined in the same way and be processed by the software using one algorithm, without branches for specific balance types. Beside certain generalizations in the form of the calibration matrix, the generic balance concept implies that a wind tunnel balance can measure an arbitrary number of physical components of load that can be transformed to a desired number of components of total loads by a user-input transformation matrix. Generally, designating the transformation matrix as $[S]$, the resultant loads $\{P\}=\{X, Y, Z, L, M, N \ldots\}^{T}$ acting on any multi-component internal balance can be calculated from balance-design-specific physical-components loads $\{F\}$, as:

$$
\{P\}=[S] \cdot\{F\}
$$

The number of rows in $[S]$ is to be equal to the number of components of total loads (i.e. $m$, usually equal to six), while the number of columns is to be equal to the number of physical balance components (i.e. $k$ ). The locations of nonzero elements in $[S]$ are specific for 
particular balance designs, as shown in (6) to (9), while the values of those terms depend both on balance design and its dimensions. These values should be derived from the theoretical (design) dimensions of the balance. Therefore, a component load transformation matrix is a descriptor of a particular balance design and size.

The designer is acually free to define the transformation matrix [S] so that it describes almost arbitrary positions and orientations of measuring components on the balance (this includes the abovementioned capability to define a balance of any type as a direct-read one). It is recommended, however, for reasons already explained, that $[S]$ be defined so that mathematical components correspond as closely as possible to physical sensors on the balance.

Beside computing total loads from physicalcomponents loads, it is often also necessary to perform the inverse computation and transform the total loads $\{P\}$ to loads $\{F\}$ acting on physical balance components. Such a situation can arise, for example, when a balance is calibrated using the global regression method, e.g. [16], and is loaded by a known force vector acting on several physical components simultaneously. If the physical components of a balance form a statically-determined system, an obvious, though not numerically optimum, approach would be to start from (10) and use the inverse of the load transformation matrix:

$$
\{F\}=[S]^{-1} \cdot\{P\}
$$

A numerically more accurate solution for the component loads could be obtained by applying one of the standard methods for solving the system of linear equations (10), in order to get $\{F\}$, without actually computing $[S]^{-1}$. On the other hand, it may be of interest to have not only the computed loads but also the inverse transformation matrix $[S]^{-1}$ available for inspection, so an algorithm that computes the inverse matrix may be preferred, after all.

Equation (11) makes sense only if the number of physical - measuring components, (elements in $\{F\}$ ) is equal to the number of components in the vector of total loads $\{P\}$. Otherwise, $[S]$ is not a square matrix, and the inverse $[S]^{-1}$ can not be made, so (11) is not applicable. Instead, the "pseudoinverse" $[S]^{+}$[17] of the transformation matrix can be used. If $k \leq m$ (there are no more physical components than components of total load), the "left pseudoinverse" can be computed as:

$$
[S]^{+}=\left[[S]^{T} \cdot[S]\right]^{-1} \cdot[S]^{T}
$$

Thereafter, the loads $\{F\}$ on physical components of a balance can be calculated from total loads as:

$$
\{F\}=[S]^{+} \cdot\{P\}
$$

It may be noted that the above relations are actually a least-squares solution of an over-constrained system, equivalent to solving a set of normal equations.
If $k>m$ (there are more physical balance components than components of total loads), $\left.[S]^{T} \cdot[S]\right]$ is a singular matrix. In such cases, the "right pseudoinverse" can be used:

$$
[S]^{+}=[S]^{T} \cdot\left[[S] \cdot[S]^{T}\right]^{-1}
$$

and applied to (13). This is equivalent to minimizing the norm of the solution of an under-constrained system.

It is known that the system of linear equations in a least-squares problem is ill-conditioned and the solution (13) is susceptible to round-off errors [18]. Besides, if a balance has redundant physical components and is not a statically determined system, (12) and (14) will encounter singularities and may not give a usable inverse matrix. The numerically superior singular value decomposition method (SVD) [18] can be used to much advantage here, and SVD should, generally, be the preferred method for computation of the inverse load transformation matrix. In the SVD procedure, $[S]$ is decomposed in a specific way into a product of three matrices:

$$
[S]=[U] \cdot[W] \cdot[V]^{T}
$$

where $[U]$ and $[V]$ are column-orthogonal matrices and $[W]$ is a diagonal matrix containing singular values of $[S]$. The pseudoinverse of the load transformation matrix is obtained as:

$$
[S]^{+}=[V] \cdot[1 / W] \cdot[U]^{T}
$$

where $[1 / W]$ is a diagonal matrix containing the reciprocals of all non-zero diagonal elements of $[W]$. The reciprocals of all zero terms, which would be infinitely large, are replaced by zeros. In practice, not only the reciprocals of zero-value terms but also of all the terms with values smaller than a certain treshold, are replaced with zeros. This should not be done blindly, and a good criterion for the rejection treshold should be applied. In this way, the unwanted singularities and near-singularities are eliminated and a "best possible approximation" of the inverse transformation matrix is obtained.

On the other hand, for all balance types so far encountered by the authors, the (pseudo)inverses of the load transformation matrices could be obtained with a good accuracy from (12) or (14) (depending on the values of $k$ and $m$ ), provided that a simple iterative procedure, outlined in [18], was always applied afterwards to improve the numerical accuracy of the computed physical-components loads: after computing the initial component loads $\{F\}_{0}$ from (12) or (14) and (13), a new approximation $\{F\}_{i}$ of component loads was obtained in each iteration $i$ as:

$$
\{F\}_{i}=\{F\}_{i-1}-[S]^{+} \cdot\left\{[S] \cdot\{F\}_{i-1}-\{P\}\right\}
$$

where $\left\{[S] \cdot\{F\}_{i-1}-\{P\}\right\}$ are the back-calculated numerical errors for that iteration. Just one or two iterations were usually sufficient to make the numerical 
round-off errors insignificant. The described iterative procedure was found to slightly improve even the solutions obtained by SVD.

The (pseudo)inverse of a load transformation matrix can usually be easily manually composed using the conditions of static equilibrium. E.g. for a typical sixcomponent force balance, with transformation matrix defined as in (8), the inverse relation would be:

$$
\left\{\begin{array}{c}
F_{Z 1} \\
F_{Z 2} \\
F_{Y 1} \\
F_{Y 2} \\
M_{X} \\
F_{X}
\end{array}\right\}=\left[\begin{array}{cccccc}
0 & 0 & -0.5 & 0 & 0.5 / a & 0 \\
0 & 0 & -0.5 & 0 & -0.5 / a & 0 \\
0 & 0.5 & 0 & 0 & 0 & 0.5 / b \\
0 & 0.5 & 0 & 0 & 0 & -0.5 / b \\
0 & 0 & 0 & 1 & 0 & 0 \\
-1 & 0 & 0 & 0 & 0 & 0
\end{array}\right] \cdot\left\{\begin{array}{c}
X \\
Y \\
Z \\
L \\
M \\
N
\end{array}\right\}
$$

\section{BENEFITS FROM USING A LOAD TRANSFORMATION MATRIX}

By a systematic application of the generic balance concept, as in the software tools [8] and [16] developed by the author, and by the definition of balance designs through load transformation matrices, certain benefits, not available otherwise, can be exploited:

- An identical wind tunnel data-reduction algorithm (or a balance-calibration algorithm) and computer code can be used for any design of internal multi-component or single-component balances, and also for some external balances that do not change position relative to the model, e.g. semi-span ones, making the "type" of the balance, as defined in [1], practically irrelevant.

- Data from unorthodox balance designs can be processed without modifications in the data-reduction software and without having to resort to calibrating the balance in other than its native load format; the number of physical components on such a balance need not be limited to six. For example, a box balance similar to the one described in [11] may have four normal-force physical components and four side-force physical components, all measured on columns at the corners of the balance body, and one axial-force component measured on a centrally placed sensing element (Fig. 6).

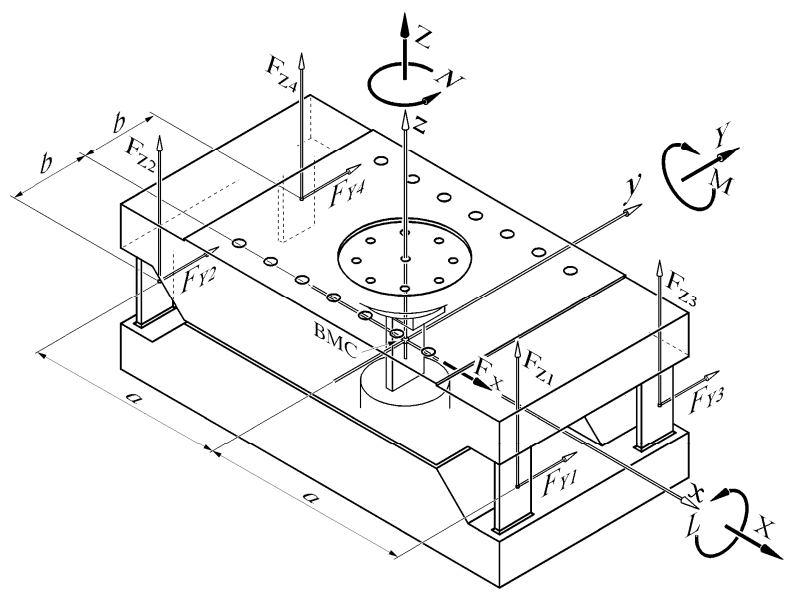

Figure 6. Possible disposition of physical and total-load components on a nine-component box-balance

If such a balance is calibrated as a nine-component one (the manufacturer calibrates it as a six-component direct-read balance using a non-iterative mathematical model [1]), it can yield actual loads on all physical components. The loads transformation matrix will then have 6 rows by 9 columns and the transformations will be, adopting an arbitrary (the manufacturer's one being unknown) $\quad x, y, y \ldots z, z \ldots$ sequence of physical components:

$$
\left\{\begin{array}{c}
X \\
Y \\
Z \\
L \\
M \\
N
\end{array}\right\}=\left[\begin{array}{ccccccccc}
1 & 0 & 0 & 0 & 0 & 0 & 0 & 0 & 0 \\
0 & 1 & 1 & 1 & 1 & 0 & 0 & 0 & 0 \\
0 & 0 & 0 & 0 & 0 & 1 & 1 & 1 & 1 \\
0 & 0 & 0 & 0 & 0 & -b & -b & b & b \\
0 & 0 & 0 & 0 & 0 & -a & a & -a & a \\
0 & a & -a & a & -a & 0 & 0 & 0 & 0
\end{array}\right] \cdot\left\{\begin{array}{l}
F_{X} \\
F_{Y 1} \\
F_{Y 2} \\
F_{Y 3} \\
F_{Y 4} \\
F_{Z 1} \\
F_{Z 2} \\
F_{Z 3} \\
F_{Z 4}
\end{array}\right\}
$$

- Additional components of total loads can be easily accounted for, that need not be forces and moments, but can be various influential variables such as temperature [19], pressure of the flow-through air [20], rotation rate of a rotary balance, etc. measured by suitable sensors on the balance or nearby. These can be included as physical components in the calibration matrix, and may as well (but need not) be represented as components of total loads, thus providing an easy way to obtain the values of those variables without any specific computational provisions. For example, the experimental high-stiffness moment balance [19] that was successfully used in VTI in tests of high-drag models e.g. [21], has a temperaturesensing bridge near the axial-force semiconductorstrain-gauges bridge on the balance body and temperature is included both as a physical component in the calibration matrix and as a component of total load so that the vector of physical components and the vector of total loads each have 7 elements:

$$
\left\{\begin{array}{c}
X \\
Y \\
Z \\
L \\
M \\
N \\
T
\end{array}\right\}=\left[\begin{array}{ccccccc}
1 & 0 & 0 & 0 & 0 & 0 & 0 \\
0 & 0 & 0 & 0 & -0.5 / b & 0.5 / b & 0 \\
0 & 0 & 0.5 / a & -0.5 / a & 0 & 0 & 0 \\
0 & 1 & 0 & 0 & 0 & 0 & 0 \\
0 & 0 & 0.5 & 0.5 & 0 & 0 & 0 \\
0 & 0 & 0 & 0 & 0.5 & 0.5 & 0 \\
0 & 0 & 0 & 0 & 0 & 0 & 1
\end{array}\right] \cdot\left\{\begin{array}{c}
F_{X} \\
M_{X} \\
M_{Y 1} \\
M_{Y 2} \\
M_{Z 1} \\
M_{Z 2} \\
T_{X}
\end{array}\right\}(20)
$$

- Transfer of balance calibration data or the balances themselves between wind tunnel communities using different axis and sign conventions is facilitated. The (unwieldy) calibration matrix and the sequence of physical components can be kept in the source format (preferably in the design-specific load format), and only the (simple) transformation matrix rearranged to suit the conventions at the site where the balance is to be used. If the order of components of total loads for a balance does not match the local conventions, the positions of appropriate rows in the transformation matrix should be interchanged. If the positive direction of a component of total load does not match the local conventions, the 
signs of all elements in the appropriate row of the transformation matrix should be changed. As a load transformation matrix will, in most cases, have no more than six rows or columns, this rearrangement can be easily performed manually. As an example, the load transformations for a typical force balance, given in (8) in matrix form according to West-European conventions, can be rearranged in accordance with North-American practice and nomenclature, to:

$$
\left\{\begin{array}{c}
N F \\
P M \\
S F \\
Y M \\
R M \\
A F
\end{array}\right\}=\left[\begin{array}{cccccc}
1 & 1 & 0 & 0 & 0 & 0 \\
a & -a & 0 & 0 & 0 & 0 \\
0 & 0 & 1 & 1 & 0 & 0 \\
0 & 0 & b & -b & 0 & 0 \\
0 & 0 & 0 & 0 & 1 & 0 \\
0 & 0 & 0 & 0 & 0 & 1
\end{array}\right]\left\{\begin{array}{c}
N F 1 \\
N F 2 \\
S F 1 \\
S F 2 \\
R M \\
A F
\end{array}\right\}
$$

- A balance can be deployed keeping the manufacturer-defined sequence and positive directions of components, without a need to change the polarities of any signals or the sequence of components in order to suit the user's conventions, so that original documentation, manufacturer's colour-coding of cabling, illustrations, etc. can remain relevant.

- With a calibration matrix kept in the native format, and with a transformation matrix defined so that mathematical components correspond to physical measuring components, the earlier-mentioned problems related to bidirectionality, nonconverging computation of loads, complicated monitoring of overloads, etc. are less likely to occur.

- The load transformation matrix, having few rows and columns and most of the elements equal to zero, can be easily composed and modified manually (contrary to the, usually much larger, calibration matrix) to suit a particular local convention regarding the orientation of load components.

- The load transformation matrix can be used to easily change the position of the BMC of a wind tunnel balance, which may occasionally be needed.

- The load transformation matrix can be very illustrative and is easily understood when viewing or discussing an unfamiliar balance design.

\section{POSSIBLE COUNTER-ARGUMENTS}

Several objections may be raised against the use of matrix notation and computations in performing the conversions between physical balance component loads and total loads:

- The formulation of the inverse transformation matrix in order to compute physical-components loads from total loads, if performed by software, is a non-trivial task requiring good library subroutines, and may be considered complicated. If SVD is used to perform the calculations, a good choice of the singularity-rejection criteria is required. A dedicated, well tested, software subroutine/function would probably be needed to perform this calculation in any actual implementation. This objection stands.

- In the proposed usage of the load transformation matrix it is implicitly assumed that a balance calibration matrix contains terms only for the actually existing physical components, without any "placeholders". This is contrary to the recommendations in [1] which advocate the universal use of a $6 \times 96$ calibration matrix, with "empty" rows and columns in the places for non-existing physical components. However, a universal $6 \times 96$ matrix and a calibration in the "physical design" load format are not simultaneously applicable anyway if a balance has more than six components, so a "compacted" calibration matrix, as implied in this paper, is more general, irrespective of the use of load transformation matrices.

- The concept of the load transformation matrix, as presented above, is not applicable to balances in which the test object (i.e. the wind tunnel model) changes position relative to the metric end of the balance.

- A load-transformation matrix can not compensate all differences in local conventions when balance calibration data are transferred between wind tunnel facilities. If a balance calibration matrix contains nonlinear terms, there can be variations in the ordering of those terms, i.e. in the sequence of members of $\left\{F^{*}\right\}$ in (1), between the origin and the destination sites. They can not be compensated by adjusting the transformation matrix and must be accounted for elsewhere, either in the computational algorithm, or, preferably, in the matrix-export utilities at the balance calibration site.

\section{CONCLUSIONS}

Representation of the transformation of physicalcomponents loads of a wind tunnel balance into total loads using matrix notation is a technique that does not seem to have come into widespread use. It has been shown that it may be convenient to put it in practice, for a number of reasons. The main advantages are: i) the possibility to use identical, generalized, computation algorithms for all types of internal and semi-span wind tunnel balances, irrespective to the number of physical balance components and not being restricted to the "force", "moment" or "direct read" balance types; ii) the possibility to always work with the balance calibration matrix in the optimum, balance-design load format, iii) the capability to easily handle, without any specific provisions in the software, balances with additional calibration variables which are not actual loads in terms of forces/moments, and iv) a facilitated transfer of balances calibration data or the balances themselves between wind tunnel laboratories and/or balance calibration laboratories with different axes and sign conventions.

While several objections to the use of a load transformation matrix can be raised as well, it is considered that the advantages outweigh the objections. It is, therefore, suggested that a load transformation matrix be generally adopted to describe the geometry of a wind tunnel balance in wind tunnel data-reduction, in balance calibration and in exchanges and presentations of balance design data, and that it should always accompany a balance, together with a calibration matrix. The calibration matrix itself should always be in the "native" or "design" format having the sequence of 
physical components and positive directions of the components as specified by the balance manufacturer, the conversion to the user's conventions being done in the transformation matrix only. Both the calibration matrix and the load transformation matrix should be general matrices with numbers of rows and/or columns corresponding to a particular physical design and calibration model.

\section{REFERENCES}

[1] AIAA/GTCC Internal Balance Technology Working Group: Recommended Practice Calibration and Use of Internal Strain-Gage Balances With Application to Wind Tunnel Testing, AIAA-R-091-2003, American Institute of Aeronautics and Astronautics, Reston, US, 2003

[2] Hufnagel, K. and Schewe, G: Force and Moment Measurement in: Tropea, C., Yarin, A.L., and Foss, J.F., (Ed.): Springer Handbook of Experimental Fluid Mechanics, Springer-Verlag, Berlin Heidelberg, 2007, Chap.8, pp. 563-616

[3] AIAA/GTCC Internal Balance Technology Working Group: Guide, Nomenclature and Axis Systems for Aerodynamic Wind Tunnel Testing, AIAA-G-129-2012, American Institute of Aeronautics and Astronautics, Reston, US, 2012

[4] Wright, J.: A Compilation of Aerodynamic Nomenclature and Axes Systems, NOLR 1241, US Naval Ordnance Laboratory, White Oak, Silver Spring, US, 1962

[5] Chugunov, G.P., Gorbushin, A.R., Kuleshov, A.Ye., Petronevich, V.V., Sudakova, I.A., Tikhomirov, V.I., Volobuyev, V.S.: Two Methods for Calibration of Strain Gauge Balances Using the TsAGI 6GS-20 Balance Calibration Machine, 8th International Symposium on Strain Gauge Balances, Lucerne, Switzerland, 7-10.05.2012

[6] Krasnov, N.F.: Aerodynamics, Mir Publishers, Moscow, 2012

[7] Philipsen, I., and Zhai, J.: Comparative Study of Strain-Gauge Balance Calibration Procedures Using the Balance Calibration Machine, AIAA2007-143, Proceedings of the 45th AIAA Aerospace Sciences Meeting, Reno, US, 8-11.01.2007

[8] Vuković, Dj.: Generalization of Data Reduction Routines for Model Attitude, Force and Moment Measurements in the Wind Tunnels of the Aeronautical Institute Žarkovo, ICAS Proceedings 1996: 20th Congress of the International Council of the Aeronautical Sciences, Sorento, Italy, 813.09.1996, pp. 825-833.

[9] Ulbrich, N., and Bader, J.: Analysis of Sting Balance Calibration Data Using Optimized Regression Algorithms, AIAA-2009-5372, 45th AIAA/ASME/SAE/ASEE Joint Propulsion Conference and Exhibit, Denver, US, 2-5.08.2009.

[10] Strain Gauge Balances for High Loads, Brochure 04.10/1500, RUAG Aviation, Emmen, Switzerland, 2010
[11]Zimmermann, C., Häberli, W., and Monkewitz, M.: Mono-bloc Balance for High Loads, Proceedings of the 5th International Symposium on Strain Gauge Balances, Modane, France, 9-12.05.2006

[12] Galway, R.D.: A Comparison of Methods for Calibration and Use of Multi-Component Strain Gauge Wind Tunnel Balances, Aeronautical Report LR-600, National Research Council of Canada, Ottawa, 1980

[13] Ulbrich, N., Influence of Primary Gage Sensitivities on the Convergence of Balance Load Iterations: AIAA-2012-0322, 50th Aerospace Sciences Meeting Including the New Horizons Forum and Aerospace Exposition, Nashville, US, 9-12.01.2012

[14] Medved, B., and Elfstrom, G.: The Yugoslav 1.5m Trisonic Blowdown Wind Tunnel, AIAA-86-0746CP, A Collection of technical papers-14th AIAA Aerodynamic Testing Conference, West Palm Beach, US, 5-7.03.1986

[15] Damljanović, D., Rašuo, B.: Testing of Calibration Models in Order to Certify the Overall Reliability of the Trisonic Blowdown Wind Tunnel of VTI, FME Transactions, Vol. 38, No. 4, Faculty of Mechanical Engineering, Beograd, 2010, pp. 167172

[16] Vuković, Dj., Samardžić, M., and Marinkovski, D.: Upgrade of the Balance Calibration System in VTI, 8th International Symposium on Strain Gauge Balances, Lucerne, Switzerland, 7-10.5.2012

[17] Chong, E.K.P., and Żak, S.H.: An Introduction to Optimization, 2nd Edition, John Willey \& Sons Inc., NY, US, 2001, Chap. 12, pp. 187-212

[18] Press, W.H., Teukolsky, S.A., and Wetterling, W.T.: Numerical Recipes in Fortran 77 - The Art of Scientific Computing, Second Edition, Cambridge University Press, New York, 2001, Vol.1, Chap. 2, pp. 22-62, Chap.15, pp. 650-700

[19] Vuković, Dj., Samardžić, M., and Vitić, A.: Prototype of a Stiff Wind Tunnel Balance With Semiconductor Strain Gauges and Thermocompensation Done by Software, 26th Congress of the International Council of the Aeronautical Sciences, Anchorage, US, 14-19.09.2008, Paper ICAS2008-P2.9

[20] Booth, D., and Ulbrich, N.: Calibration and Data Analysis of the MC-130 Air Balance, 8th International Symposium on Strain Gauge Balances, Lucerne, Switzerland, 7-10.05.2012

[21] Damljanović, D., Mandić, S., and Vuković, Dj.: Computational fluid dynamics and wind tunnel determination of the aerodynamic characterstics of an axi-symmetric projectile with a conical tail flare, Scientific Technical Review, Vol. 61, No. 3-4, Vojnotehnički institut, 2011, pp. 49-55

\section{NOMENCLATURE}

Diverse variables

a half-distance between normal-force or pitching-moment bridges on a wind tunnel balance 
half-distance between side-force or yawingmoment bridges on a wind tunnel balance iteration count

$k \quad$ number of physical components of a wind tunnel balance

$m$ number of components of total loads (usually equal to six)

Components of total loads

$L \quad$ rolling moment component of total load

$M \quad$ pitching moment component of total load

$N \quad$ yawing moment component of total load

$T$ temperature of the balance (component of total load)

$X \quad$ axial force component of total load

$Y \quad$ side force component of total load (normal force in Russian practice)

Components of total loads (American notation)

$A F \quad$ axial force (also physical component in NorthAmerican notation)

NF normal force

$P M \quad$ pitching moment

$R M$ rolling moment (also physical component in North-American notation)

$S F \quad$ side force

$Y M \quad$ yawing moment

Physical balance components

$F_{X} \quad$ axial force

$F_{Y} \quad$ side force

$F_{Y 1} \quad$ fore side force

$F_{Y 2} \quad$ aft side force

$F_{Y 3} \quad$ third side force

$F_{Y 4} \quad$ fourth side force

$F_{Z} \quad$ normal force

$F_{Z 1} \quad$ fore normal force

$F_{Z 2} \quad$ aft normal force

$F_{Z 3} \quad$ third normal force

$F_{Z 4} \quad$ fourth normal force

$M_{X} \quad$ rolling moment

$M_{Y} \quad$ pitching moment (also yawing moment component of total load in Russian practice)

$M_{Y 1} \quad$ fore pitching moment on a moment balance

$M_{Y 2} \quad$ aft pitching moment on a moment balance

$M_{Z} \quad$ yawing moment (also pitching moment component of total load in Russian practice)

$M_{Z 1} \quad$ fore yawing moment on a moment balance

$M_{Z 2} \quad$ aft yawing moment on a moment balance

$T_{X} \quad$ measured temperature of the balance

Physical balance components (American notation)

$N F 1$ fore normal force on a force balance

NF2 aft normal force on a force balance

$S F 1$ fore side force on a force balance

SF 2 aft side force on a force balance
Column vectors and matrices

[C] calibration matrix of a wind tunnel balance

[C1] linear part of the calibration matrix of a wind tunnel balance

[C2] nonlinear part of the calibration matrix

$\{e\} \quad$ column vector of $(k \times 1)$ normalized output signals from physical components

$\{F\}$ column vector $(k \times 1)$ of loads on physical measuring components of a balance

$\left\{F^{*}\right\} \quad$ column vector of load products etc. modeling the behaviour of a balance

$\{P\} \quad$ column vector $(m \times 1)$ of components of total loads (axial force, normal force, etc.)

[S] load transformation matrix ( $m$ rows by $k$ columns)

$[S]^{+} \quad$ pseudoinverse of the load transformation matrix

$[U]$ matrix of left-singular-vectors produced by SVD ( $m$ rows by $k$ columns)

[V] matrix of right-singular-vectors produced by SVD ( $k$ rows by $k$ columns)

$[W]$ diagonal matrix of singular values produced by SVD ( $k$ rows by $k$ columns)

$[1 / W]$ diagonal matrix of reciprocal or zeroed singular values ( $k$ rows by $k$ columns)

\section{О УПОТРЕБИ МАТРИЦА ТРАНСФОРМАЦИЈЕ ОПТЕРЕЪЕЊА ПРИ РАДУ СА УНУТРАШЫИМ АЕРОВАГАМА}

Ђорђе Вуковић, Дијана Дамљановић

Унутрашње аероваге се често разврставају, по свом дизајну, на „аероваге са мерењем сила“, „моментне аероваге“" и ,,аероваге са директним очивавањем“. Само аероваге са директним очитавањем могу одмах да дају укупна оптерећења; код других типова су неопходне трансформације, зависне од типа аероваге, стварно мерених оптерећења на укупна оптерећења. Показује се да представљање ових трансформација у матричном облику, у виду „матрице трансформације оптерећења“, осим што представља погодан начин да се изведе прорачун, омогућава значајне генерализације у обради података, практично елиминишући потребу за „типом“ аероваге. Употреба матрице трансформације такође олакшава размену баждарних података за аероваге, као и самих аеровага, међу аеротунелским заједницама са различитим конвенцијама које се односе на осе и смерове оптерећења. Предлаже се да се, због погодности које омогућава, матрица трансформације оптерећења употребљава ради описивања дизајна аеровага и да увек прати сваку аеровагу, заједно са баждарном матрицом. 